\title{
Injury in summer rugby league football: the experiences of one club
}

\author{
C Gissane, D Jennings, J White, A Cumine
}

\begin{abstract}
Objective-To investigate whether the movement of the playing season from winter to summer would alter the risk of injury to players taking part in first team European professional rugby league.

Methods-The study design was a historical cohort design comparing winter and summer seasons in first team European rugby league, which recorded injuries received by players during match play. Each injury was classified according to site, type, player position, activity at the time of injury, and time off as a result of injury.

Results-The risk of injury when playing summer rugby league was higher than when playing winter rugby league (relative risk $=1.67(95 \%$ confidence interval 1.18 to 2.17)). Both forwards (1.08 (0.28 to 1.88$)$ ) and backs (2.36 (2.03 to 2.69)) experienced an increased risk of injury.

Conclusions-Summer rugby may have resulted in a shift of injury risk factors as exhibited by a change in injury patterns. This may be due to playing conditions, but there were also some law changes. Changes in playing style, team tactics, player equipment, fitness preparation, and the reduced preseason break may also have had confounding effects on injury risk.
\end{abstract}

(Br F Sports Med 1998;32:149-152)

Keywords: rugby league; injury; injury risk; summer rugby; cohort study

Studies of injury in rugby league football have previously reported rates of injury ${ }^{1-4}$ higher than for many other team sports. ${ }^{3}$ The reason for this high injury rate is probably the high number of physical collisions in which players are involved during the course of a game. ${ }^{1} \mathrm{With}$ increasing professionalism in the sport, injuries are an important issue, both in terms of team success and the livelihood of the players themselves. ${ }^{3}$

The year of 1996 saw a bold move, with European rugby league taking place in the spring and summer months, as opposed to its more traditional time of autumn, winter, and spring. This move meant that matches would be played in higher temperatures (London temperature (mean (range)) in September to April $9.5(6-14)^{\circ} \mathrm{C}$ and in April to September $\left.18.6(13-22)^{\circ} \mathrm{C}\right)$ and on harder surfaces. There would, however, be one third fewer competitive matches to be played, because of the restructuring of the league (12 teams) and the elimination of two cup competitions. Injury studies carried out in Australia ${ }^{135}$ have consistently reported higher injury rates than English studies, ${ }^{24}$ and it was surmised that this was due to the game being played on harder surfaces. ${ }^{4}$ Playing rugby league in the summer months may also increase the likelihood of players suffering from thermal injuries and heat stroke, as the result of a combination of higher temperatures and relative humidities. ${ }^{6-8}$

It is unusual for a sport to completely change its playing calendar, and this move may result in an alteration in the risk of injury to players. Therefore the purpose of the present study was to ascertain whether or not the movement of the playing season from the autumn and winter months to the spring and summer months would alter the risk of injury to players taking part in professional rugby league in the new European Super League established in March 1996.

\section{Methods}

During the initial European Super League season all injuries that were reported for the first team at one professional rugby league club were recorded. The injury data were compared with first team data from a previous study on the same club over a period of four seasons. ${ }^{4}$ An injury was defined as a physical impairment received during a competitive match which

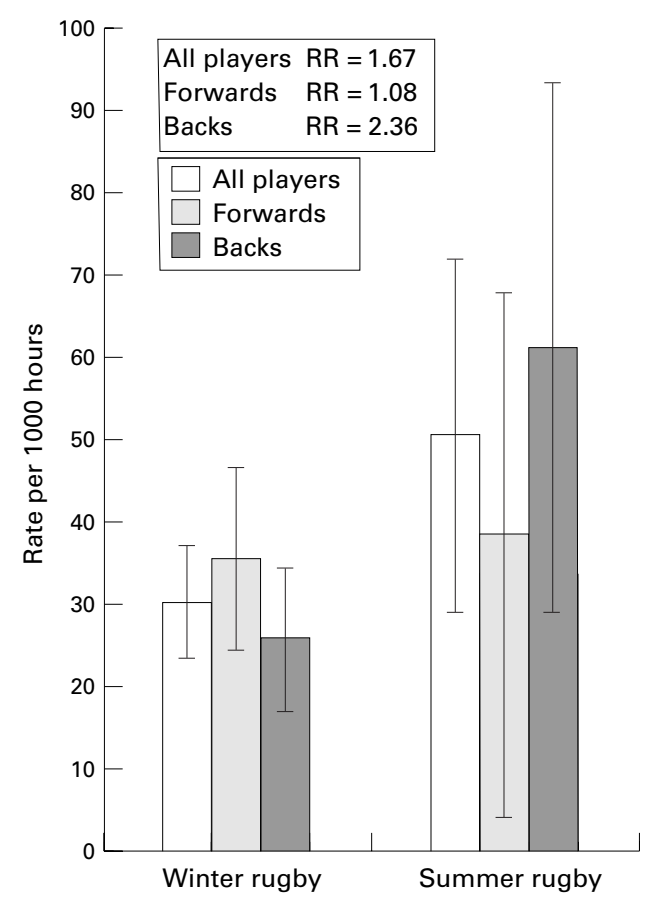

Figure 1 Comparison of injury rates for winter and summer rugby league (with 95\% confidence interval). 
Table 1 Relative risk of types of injury

\begin{tabular}{|c|c|c|c|c|c|c|}
\hline & \multicolumn{2}{|c|}{ Winter } & \multicolumn{2}{|c|}{ Summer } & \multirow[b]{2}{*}{$R R$} & \multirow[b]{2}{*}{$95 \% C I$} \\
\hline & No & $\begin{array}{l}\text { Rate per } 1000 \\
\text { hours }\end{array}$ & No & $\begin{array}{l}\text { Rate per } 1000 \\
\text { hours }\end{array}$ & & \\
\hline Haematomas & 4 & 1.68 & 2 & 5.03 & $3.00^{\star}$ & 1.3 to 4.7 \\
\hline Muscle strains & 18 & 7.54 & 1 & 2.51 & 0.33 & -1.7 to 2.4 \\
\hline Muscular injuries (total) & 22 & 9.22 & 3 & 7.54 & 0.82 & -0.4 to 2.0 \\
\hline Joint sprain & 25 & 10.48 & 8 & 20.12 & $1.92^{\star}$ & 1.1 to 2.7 \\
\hline Laceration & 4 & 1.68 & 0 & - & - & - \\
\hline Contusion & 4 & 1.68 & 0 & - & - & - \\
\hline Fracture and dislocation & 8 & 3.35 & 7 & 17.60 & $5.25^{\star}$ & 4.2 to 6.3 \\
\hline Concussion & 8 & 3.35 & 1 & 2.51 & 0.75 & -1.3 to 2.8 \\
\hline Others & 1 & 0.42 & 1 & 2.51 & $6.00^{\star}$ & 3.2 to 8.8 \\
\hline All injuries & 72 & 30.18 & 20 & 50.29 & $1.67^{\star}$ & 1.2 to 2.2 \\
\hline
\end{tabular}

$\mathrm{RR}$, relative risk; CI, confidence interval.

$\star \mathrm{p}<0.05$.

prevented a player from being available for selection for the next competitive game. ${ }^{1}$ The games were 7 (1.09) (mean (SD)) days apart. The diagnosis and classification of injury was carried out by the club doctor and physiotherapist. The type of information recorded for each injury has been described previously. ${ }^{2} 49$

The population at risk was defined as the players who were selected to play for the first team in a given match, and the defined time at risk for calculating injury rates was the duration of the games multiplied by the number of players ( 1.33 hours $\times 13$ players) multiplied by the number of games played. The average number of games played during the winter season was 34.5 (596.5 player hours), with each player averaging 12.1 appearances per season, and during the summer season 23 games (397.67 player hours) were played in the Super League of 1996, with each player averaging 8.3 appearances.

Statistical analyses consisted of the calculation of injury rate per 1000 hours of play as a standardised rate of exposure. ${ }^{10}$ To calculate the relative risk (RR) of injury between winter and summer rugby league, we used the incidence density ratio (IDR) method described by Hennekens and Buring ${ }^{11}$ for the two cohorts.

RR $($ IDR $)=\frac{\text { No of summer injuries/exposure time (hours) }}{\text { No of winter injuries/exposure time (hours) }}$

Confidence intervals (95\% CI) were calculated using the method described by $\mathrm{McNeil} .{ }^{12}$ Where the CI did not contain the null value $(R R=1.0)$, the $R R$ was taken as being significant at the $\mathrm{p}<0.05$ level. ${ }^{11}$

\section{Results}

There was no significant difference between the ages of the two cohorts of players investigated (winter 24.2 (2.5) years, summer 25.7 (3.9) years (mean (SD)) $(t=0.76, \mathrm{df}=$ $69, \mathrm{p}=0.448)$. Figure 1 shows the injury rates for summer and winter rugby league for all players: summer rugby league had a higher injury rate than winter rugby league, the actual risk of injury in summer rugby league being $67 \%$ higher than in winter rugby league $(\mathrm{RR}=$ 1.67 (95\% CI 1.18 to 2.17 )).

The injury rates for forwards and backs were analysed separately (fig 1). The injury rate for forwards was slightly higher for summer rugby league (an $8 \%$ increase; $\mathrm{RR}=1.08$ (95\% CI 0.28 to 1.88$)$ ). The backs had a much larger increase in injury rates when playing rugby league in the summer. The RR of $2.36(95 \% \mathrm{CI}$ 2.03 to 2.69 ) indicated that the risk of injury increased $136 \%$ on changing the playing season from winter to summer.

Table 1 shows that there were significantly increased risks during summer rugby of haematomas, fractures and dislocations, joint injuries, and others (all $\mathrm{p}<0.05$ ). Similarly, there was significantly increased risk of injury to the shoulder, arm, and other sites of the body (all $\mathrm{p}<0.05$ ), and overall, there was significantly greater risk of injury to the lower body $(p<0.05)$ (table 2). There was an increased risk of being injured in the "others" activity category, which included such activities as running and catching high balls, in summer when compared with winter rugby $(p<0.05)$, while the injury risk when tackling or being tackled did not alter significantly (table 3 ).

Table 2 Relative risk of injury to anatomical sites of the body

\begin{tabular}{|c|c|c|c|c|c|c|}
\hline & \multicolumn{2}{|c|}{ Winter } & \multicolumn{2}{|c|}{ Summer } & \multirow[b]{2}{*}{$R R$} & \multirow[b]{2}{*}{$95 \% C I$} \\
\hline & No & $\begin{array}{l}\text { Rate per } 1000 \\
\text { hours }\end{array}$ & No & $\begin{array}{l}\text { Rate per } 1000 \\
\text { hours }\end{array}$ & & \\
\hline Thigh and calf & 13 & 5.45 & 2 & 5.03 & 0.90 & -0.6 to 2.4 \\
\hline Knee & 9 & 3.77 & 3 & 7.54 & 2.00 & 0.7 to 3.3 \\
\hline Ankle & 8 & 3.35 & 1 & 2.51 & 0.75 & -1.3 to 2.8 \\
\hline Shoulder & 7 & 2.93 & 3 & 7.54 & $2.57^{\star}$ & 1.2 to 3.9 \\
\hline Arm & 3 & 1.26 & 2 & 5.03 & $4.00^{\star}$ & 2.2 to 5.8 \\
\hline Head and neck & 19 & 7.96 & 3 & 7.54 & 0.95 & -0.3 to 2.2 \\
\hline Thorax and abdomen & 11 & 4.61 & 2 & 5.03 & 1.09 & -0.4 to 2.6 \\
\hline Others & 2 & 0.84 & 4 & 10.06 & $12.00^{\star}$ & 10.3 to 13.7 \\
\hline Upper body & 41 & 17.18 & 10 & 25.15 & 1.46 & 0.8 to 2.1 \\
\hline Lower body & 31 & 12.99 & 10 & 25.15 & $1.94^{\star}$ & 1.2 to 2.6 \\
\hline
\end{tabular}

$\mathrm{RR}$, relative risk; CI, confidence interval.

${ }^{\star} \mathrm{p}<0.05$. 
Table 3 Activity at the time of injury

\begin{tabular}{|c|c|c|c|c|c|c|}
\hline & \multicolumn{2}{|c|}{ Winter } & \multicolumn{2}{|c|}{ Summer } & \multirow[b]{2}{*}{$R R$} & \multirow[b]{2}{*}{$95 \% C I$} \\
\hline & No & Rate per 1000 hours & No & Rate per 1000 hours & & \\
\hline Tackler & 15 & 6.29 & 7 & 17.60 & 2.7 & 0.9 to 3.7 \\
\hline Tackled & 39 & 16.35 & 7 & 17.60 & 1.1 & 0.3 to 1.9 \\
\hline Other & 18 & 7.54 & 6 & 15.09 & $2.0^{\star}$ & 1.1 to 2.9 \\
\hline
\end{tabular}

$\mathrm{RR}$, relative risk; CI, confidence interval.

${ }^{\star} \mathrm{p}<0.05$.

\section{Discussion}

The major findings of the present study were the increased injury rates and the increased risk of injury associated with summer rugby league in both forward and back players, but the data suggest that the increased risk of injury was proportionately greater in backs than forwards.

The data for this study were collected prospectively as part of a continuing investigation, which is a necessary process so that changing injury rates can be taken into account when playing conditions, training, and fixtures are being designed. ${ }^{3}$ It allowed the winter and summer cohorts to be compared, to assess changes in injury risk as a result of moving the playing calendar. It has been suggested that historical cohort study designs decrease the comparability of data. ${ }^{13}$ However, similar data were collected by the present investigators for both summer rugby league (current cohort) and winter rugby league (historical cohort), but only three players were present in both the winter and summer cohorts.

Injury rates for the summer cohort increased even though exposure time was decreased by one third, which may have been due to the altered playing conditions of warmer temperatures and harder playing surfaces. In support of this, studies in Australia, ${ }^{135}$ where temperatures during the playing season are 18.2 $(16-22)^{\circ} \mathrm{C}$ (mean (range)), have often reported higher injury rates than British studies, ${ }^{24}$ even though fewer games were played (30 games in the English league in 1994-1995 v 22 games in Australia in 1994). There is also the possibility that some injuries may have been carried over from the previous season. The last winter season before the beginning of the Super League finished in the first week of February, with the Super League beginning at the end of March. This was a 51 day period, much shorter than the three and half months between seasons as previously; players therefore did not have the time to recuperate that they had previously enjoyed. Furthermore, the move to full time professionalism could have predisposed players to injury, since full time increased training would allow players much less time for recovery. ${ }^{14}$

Forwards have been reported to receive more injuries than backs, ${ }^{1-3} 15$ as a result of being involved in more physical contact. ${ }^{4}{ }^{9}$ It is therefore unusual to find a higher rate of injury among backs and the subsequently very high relative risk in summer rugby. Alexander et al ${ }^{16}$ found more injuries to backs when the style of play changed to move the ball wider sooner, giving the backs a greater role in the game. Previous research has shown that the ball carrier is the person who is most likely to receive an injury. ${ }^{9}$ Therefore increasing the amount of time that the backs are ball carriers involves them in more physical collisions and therefore increases their risk of injury; at the same time, the amount of physical contact experienced by the forwards is reduced.

Another possible reason for backs having a higher injury rate than forwards is the introduction of the zero tackle law, which was not in place when the winter rugby data were collected. The law (2.3.1) states "When a player gathers the ball from an opposition kick in general play and does not subsequently pass or kick the ball himself, the initial tackle will be counted as a zero tackle". ${ }^{17}$ This effectively gives a team seven "play the balls" or possessions. When the ball is kicked, it is often deep in the field of play, and it is gathered by a back player, who runs to gain ground; since the ball carrier is at the highest risk of injury in a tackle, ${ }^{24}$ these law changes and playing styles could increase the risk of injury in back players.

The findings of the present study also show that there was an alteration in the risk of injury when examined by both type and site of the body. Investigations in other sports have reported alterations in injury patterns when the playing surface has been changed; for hockey ${ }^{18}$ and American Football ${ }^{19}$ increased injury rates have been reported since the use of astroturf. In American Football the risk of knee $(\mathrm{RR}=1.18)$ and ankle $(R R=1.39)$ injuries has also been shown to increase as a result of the change of playing surface. ${ }^{20}$ The changing relative risks in specific injuries seen in the present study may be due to similar mechanisms. Specifically, Fuller $^{21}$ claimed that the hard surface of artificial grass allows players to achieve higher speed, but there is decreased shock absorption capacity, and the same could be suggested for summer rugby league. The site category "others" $(R R=12.0)$ contained a number of foot injuries which previously were extremely rare, ${ }^{22}$ but their onset could be associated with turning and being tackled on the harder surface.

The first season of Super League has produced a change in injury patterns, and may have resulted in a shift of injury risk factors. This cannot be exclusively explained by the playing conditions, as there are a number of other factors that need to be considered; athletic injuries usually have many causes, making the identification of simple risk factors difficult. ${ }^{23}$ Between the end of data collection for the first cohort and the beginning of data collection for the second cohort, law changes were instituted, which may have altered the risk of injury. The shorter preseason break and the increased amount of training may influence the factors that predispose a player to injury. In addition, playing style, team tactics, and player equipment may also have altered. Any of these factors may have a confounding effect on the incidence of injury, and further investigation is needed to determine their influence.

Epidemiological investigations are needed to determine the extent of injury rates as an initial investigative step. However, rugby league has taken the very unusual step of moving its playing season, and descriptive investigations need 
to continue to document the accompanying injury risk. Preliminary findings suggest that it has increased, but surveillance needs to continue, as sport is a dynamic entity. The 1997 season will see further changes which will affect the game, the players, and almost certainly the risk of injury.

1 Gibbs N. Injuries in professional rugby league: a three year prospective study of the South Sydney professional rugby prospective study of the South Sydney professional rugby

2 Gissane C, Jennings DC, Standing S. Incidence of injury in rugby league football. Physiotherapy 1993;79:305-10

3 Seward H, Orchard J, Hazard H. Football injuries in Australia at the elite level. Med f Aust 1993;159:298-306.

4 Stephenson S, Gissane C, Jennings D. Injury in rugby league: a four year prospective survey. $\mathrm{Br} f$ Sports Med 1996;30:331-4.

5 Estell J, Shenstone B, Barnsley L. Frequency of injuries in different age-groups in an elite rugby league club. Aust $\mathcal{F ~ S c i}$ Med Sport 1995;27:95-7.

6 Savdie E, Prevedorous H, Irish A, et al. Heat stroke following rugby league football. Med f Aust 1991;155:636-9.

7 Meir R, Lowden B, Davie A. Jersey configuration in rugby league: too hot to handle? Sport Health 1994;12:22-5.

8 Meir R, Lowden B, Davie A. The effect of jersey type on thermoregulatory responses during exercise in a warm humid environment. Aust $\mathcal{F}$ Sci Med Sport 1994;26:25-31.

9 Gissane C, Jennings DC, Cumine AJ, et al. Differences in the incidence of injury between rugby league forwards and the incidence of injury between rugby league
backs. Aust F Sci Med Sport 1997;29:91-4.
10 Edgar M. Tackling rugby injuries. Lancet 1995;345:1452-3. 11 Hennekens $\mathrm{CH}$, Buring JE. Epidemiology in medicine. Boston: Little, Brown and Company, 1987

12 McNeil D. Epidemiological research methods. Chichester: John Wiley and Sons, 1996.

13 Rudicel S. How to choose a study design. Am $\mathcal{F}$ Sports Med 1988;15:s43-7.

14 Arnheim DD. Modern principles of athletic training. Boston: Mosby College Publishing, 1989.

15 Norton R, Wilson MA. Rugby league injuries and patterns. New Zealand Fournal of Sport Medicine 1995;22:37-8.

16 Alexander D, Kennedy M, Kennedy J. Rugby league football injuries over two competitive seasons Med $\mathcal{F}$ Aust $1980 ; 2: 334-5$.

17 The Rugby Football League. Super League: the international laws of the game. Leeds: The Rugby Football League, 1996.

18 Jamison S, Lee C. The incidence of female injuries on grass and synthetic playing surfaces. Aust $\mathcal{F}$ Sci Med Sport 1989; 21:15-17

19 Skovron ML, Levy MI, Agel, J. Living with artificial grass: a knowledge update. Part 2: epidemiology. Am $\mathcal{F}$ Sport Med 1990;18:510-13.

20 Powell JW, Schootman M. A multivariate risk analysis of selected playing surfaces in the national football league: 1980 to 1989 . An epidemiological study of knee injuries. Am 7 Sport Med 1992;20:686-94.

21 Fuller MI. A study of injuries in women's field hockey as played on synthetic pitches. Physiotherapy in Sport 1990;12: 3-6.

22 Jennings D, Gissane C. Turf-toe - super league toe. $B r \mathcal{F}$ Sports Med 1997;31:164.

23 Meeuwisse WH. Assessing causation in sports injury: a multifactorial model. Clin F Sport Med 1994;4:166-70.

\section{British Fournal of Sports Medicine http://www.bjsportmed.com}

Visitors to the world wide web can now access the British fournal of Sports Medicine either through the BMJ Publishing Group's home page (http://www.bmjpg.com) or directly by using its individual URL (http://www.bjsportmed.com). There they will find the following:

- Current contents list for the journal

- Contents lists of previous issues

- Members of the editorial board

- Information for subscribers

- Instructions for authors

- Details of reprint services.

A hotlink gives access to:

- BMJ Publishing Group home page

- British Medical Association web site

- Online books catalogue

- BMJ Publishing Group books.

The web site is at a preliminary stage and there are plans to develop it into a more sophisticated site. Suggestions from visitors about features they would like to see are welcomed. They can be left via the opening page of the BMJ Publishing Group site or, alternatively, via the journal page, through "about this site". 